\title{
School Factors as Correlates of Students' Achievement in Chemistry
}

\author{
Aderonke Margaret Oginni ${ }^{1}$, Victoria Yetunde Awobodu ${ }^{2}$, \\ Michael Olusegun Alaka ${ }^{3}$, Sakibu Olajide Saibu ${ }^{4}$ \\ Department of Integrated Science, School of Science, \\ Adeniran Ogunsanya College of Education, Otto/Ijanikin, Lagos, Nigeria
}

\begin{abstract}
There is abundant research evidence to support the view that when Chemistry is taught in an enabling environment, a lot of enjoyable learning takes place. But in reality this is not always so, the implication is that students' achievement in this subject still continue to dwindle. This study therefore aimed at finding the extent to which school factors predict senior secondary school students' achievement in Chemistry. Ex-post facto research type with a survey design was adopted for the study. The sample used consisted of senior secondary school Chemistry students and teachers drawn from fifty seven (57) local governments and development areas of Lagos state. Instruments were developed and validated for the study. Three research questions were raised and answered in the study. Pearson Product Moment Correlation and Multiple Regression Statistics were used to analyze data collected. Findings from the study showed that as the conditions accrued to school factors improve, the performance of students in chemistry improves. Recommendations were made based on these findings.
\end{abstract}

\section{Introduction}

Science and technology have long been recognized as instruments par excellence for nation building and every country today craves for development [14],[30],[6]. Nigeria, like the other nations in the world depends on what Science, Technology and Mathematics could offer for her national development [24],[31],[21]. Her national objectives, as stated in the National Policy on Education [20], are geared towards self realization, better human relationship, individual and national unity as well as towards social, cultural, economic, political, scientific and technological growth. To accomplish these objectives, it is stated in section 10 of the Policy that Federal and State Governments shall maintain and adequately fund the Inspectorate and Education Planning Department of their ministries of education. Indeed, the relevance of science to national goals, aspirations and economy dictates, to a large extent, the huge commitment and support which most nations make and give to science and technological development [8].

Within the context of science, Chemistry which is a branch of pure science is introduced into the curriculum content of secondary schools because of its educational value, relevance to the need of the individual learner and society as a whole [9]. Chemistry is a human endeavour

Copyright (c) 2013, Infonomics Society that relies on basic qualities like activity, weight, recording and skills [56]. Chemistry is commonly viewed as the "Central Science" as mastery of its concepts regarding the structure of matter is prerequisite to further study in all sciences. In essence, chemistry performs the function of gate keeper for the future study of both pure and applied science, Medicine, Pharmacy, Engineering, Agricultural and all other professions at the secondary school level. In another dimension, there are consistent reports in literature as regards students' performance in science in senior secondary school in Nigeria [36],[32],[45].

Also, many new curriculum projects such as Chemistry study, Elementary Science Study (ELSS) and Science Curriculum Improvement Study (SCIS) were developed and accomplished through the close collaboration of teachers and scientists, aimed at revamping the quality of science education and supporting students' science learning with good curriculum materials with a high level of science content and disciplinary knowledge [27]. Therefore to remain relevant in the society around us and also to be part of the development of new technologies, science students should be competent at mastering the necessary concepts and skills and they should be able to translate them to everyday living.

Despite the introduction of new curricula, Shinho and Oginni believes that that general level of performance of students in the subject is still not good enough [27],[7]. It is on this premise that the present study is based and some school factors considered to be militating against students' performance were investigated. The selected factors therefore include school location, school type, laboratory adequacy and frequency of practical classes.

\section{School Location and Students' Achievement in Chemistry}

There is a consensus among psychologists and educationist that a child's environment can exert considerable influence on his or her intellectual development [46]. Based on past studies, it is believed that there is need to determine the efficacy of school location on student's learning outcomes in Chemistry. Many authors have explained the importance of school factors in the achievement of students particularly in science [34],[41],[25],[17]. In the same vein, Ndukwu and Odinko noted that schools located in urban areas are better positioned to attract more quality students and 
teachers who exhibit the readiness to take academic business seriously [38][39]. Also, Capron and Duyne and Adelabu suggested in their separate studies on school location that an enriched environment could result in better performance of students [15],[35]. Furthermore, research work of Orji indicated that the environment in which a school is located, in fact, brings about different responses and behaviors from learners [42].

Studies have shown, for instance, that location of a school can affect performance in Biology and at least by deduction, should affect performance in chemistry, mathematics or other science subjects [23]. The surprise however, is that unlike previous studies which suggest that the effect of location is in favour of urban students, the result in Okonkwo's study suggests the opposite [46]. This might suggest according to him, that the effect of location might not be absolute. It was therefore part of the thrust of this study to investigate the influence of school location among other factors on students' achievement in chemistry.

\subsection{School Types and Students' Achievement in Chemistry}

Also, the debate on whether private schools should be allowed to thrive or be abolished is always on. Solarin in his article titled, "Educational Apartheid in Nigeria" called on the federal government to ban the existence of Army children schools, voluntary agency schools, private schools and federal government colleges [52]. Very close to this view, Kobune sees the recent clampdown on private schools in Lagos as a welcome idea. She believes that mopping out schools delivering a watered-down education after parents paid so much for the education of their children is a good idea [12].

Okonkwo found that children who attended private primary schools generally came into secondary schools more 'ready' for junior secondary school mathematics than did their public school counterparts [46]. Also, Okonkwo in his study concluded that some 10 percent $(10 \%)$ of variance in the subjects' mathematics scores is uniquely accounted for by the type of school, after the location effect had been statistically controlled for. The notion that pupils in private primary schools are better academic achievers' than their counterparts in public primary schools is dependent on the assumption that private schools are adequately equipped with human and material resources and that those resources are channeled towards a purposeful educational objectives authoritatively.

\subsection{Laboratory Adequacy and Students' Achievement in Chemistry}

The place of laboratory in science teaching is not a neglected issue [28]. Several studies of the social interactions within which lessons in the laboratory are constituted also exist [51].

Copyright (c 2013, Infonomics Society
Wong and Fraser found significant association between the nature of the chemistry laboratory classroom environment and the students' learning outcomes [57]. Tai, Sadler and Loehr uncovered several interesting high school pedagogical experiences that appeared to be linked with varying laboratories for understanding associated with higher students grade [58]. Whereas over emphasis on laboratory procedure in high school chemistry was associated with lower grades in College. These results suggested that high school teachers pedagogical choice may have a link to future students performance.

Tai, Sadler and Lochr also affirmed that students reporting more instances of repeating laboratory to enhance their understanding earned higher chemistry grades than their peers who reported few or no instances of repeating laboratory for understanding [58]. They emphasized therefore that laboratory work holds greater promise in helping to prepare students for higher level studies.

Researchers like Nwosu and Bassey reported inadequate resources materials in science teaching [4], [6]. They further stated that where there are little resources at all, they are not usually in good condition while the few ones that are in good condition are not enough to go round those who need them. This poses a great challenge to government on the need to raise the funding needs of schools where science subjects such as chemistry are being offered. This is because where the materials are not available in large quantities to meet the demand, effective teaching and learning of science, especially chemistry which is the queen of the sciences becomes very difficult [13], [44]. In this case, only but the highest creative, resourceful, committed and dedicated teachers can resort to improvisation of scarce resources. Effiong-Edem in his study concluded that to avoid the prospect of a possible negative background, there should be provision of adequate laboratory and equipment, this study therefore probed more into this [37].

\subsection{Practical classes and students' achievement}

Frequency of practical classes is also an important school factor since scientific process skills such as observation and prediction involves "doing" and doing means practical activity. It is assumed that frequent use of laboratory for practical lessons by the teacher can translate chemical knowledge to the understanding of scientific facts, laws and theories. Students Acquisition of Practical skills with reasonable accuracy in laboratory based teaching in the heart of experimental subjects like Chemistry, Nwosu and Jimoh both oriented out that the use of laboratory activities outweighs other methods of science teaching. This is to show that the efficacy of frequency of practical teaching to unravel the mystery behind perception of Chemistry concepts is not in doubt [4], [10].

Salt observed that the "talk and chalk" method hardly increased students' enthusiasm and interest. It is 
observed that students "develop conceptual understanding through engagement in hands-onactivity" [50][1]. Being a major tenet of Piagetian constructivism, it assumes that learners are exposed to a variety of hands-on-experiences where they understand what they do and are able to construct new level of understanding. It demands active involvement of learners to reflect on their learning, make inferences and to experience conflict. When this happens, learners become aware of their own cognitive process a situation which Garner refers as metacognition [43].

Furthermore, students' reactions to practical work often confirm the view of critics in that students find that laboratory classes are boring and that they go through the motions of experimentation without stimulation and often without any clear purpose. But, because research has not been comprehensive, we simply do not know enough about the effects of laboratory instruction upon student learning [23]. Gallargher concluded that laboratory work is an accepted part of science instruction [29]. The extent to which laboratory activities affect the achievement of students in chemistry in particular and science in general is therefore part of the purpose of this study.

\subsection{Statement of the Problem}

The fact that students' performance in Chemistry and in the sciences at the secondary school level is low is no longer news. Several researchers have reported the downward trend in the performance of Nigeria students in science and chemistry in particular. Oloruntegbe and Orifa affirmed this that not only the results of students in chemistry getting worse but also the recipients are getting progressively unscientific in their thought pattern and approach to solving problems. Several factors have been reported responsible for this decline in students' performance. It is on this premise that this study investigated the extent to which school factors (school location, school type, laboratory adequacy and frequency of practical classes) predict senior secondary school students' achievement in chemistry.

\subsection{Research Questions}

1. What is the composite effect of the selected school factors (school location, school type, laboratory adequacy and frequency of practical class) on student's achievement in chemistry?

2. What are the relative effects of the school factors on students' achievement in chemistry?

3. Which of the school factors would predict students' achievement in chemistry?

\section{Methodology}

\subsection{Research design}

This study adopted the ex-post facto research type with a survey design. The investigator only studied them retrospectively in terms of their relationship with the dependent variable.

\subsection{Variables in the study}

The variables in the study include the following independent variables viz school location, school type, laboratory adequacy and frequency of practical classes, while the dependent variable is students' achievement in chemistry.

\subsection{Population and Sample}

The population of the study consisted of SS II Chemistry students and teachers in Lagos State. All the secondary schools in the 57 Local Government and Development Areas of Lagos State were first stratified into urban and peri-urban based on water supply, social amenities, electricity, and population. Ten (10) urban schools consisting of seven (7) public and (3) three private schools and ten (10) peri-urban schools consisting of seven (7) public and three (3) private were then randomly selected for the study. All the SS II chemistry students in the selected schools and their teachers were used for the study.

\subsection{Instrument}

Questionnaires were used to test for the effect of school factor on student's achievement in the following tests:

- Mathematical Ability Test (MAT)

- Student Practical Skills Test (SPST)

- Student Mental Ability Test (SMAT)

- Student Achievement Test (SAT)

\subsection{Validation of MAT}

MAT was validated using test-re-test method. The correlation coefficient between the two sets of scores was calculated using Pearson's product moment correlation formula to determine the reliability of the instrument. The reliability index obtained was 0.89 .

\subsection{Scoring of MAT}

MAT was scored by awarding a point to each correct response made by the student and zero for wrong ones 


\subsection{Validation of SPST}

The SPST was tested for reliability using the test-retest method which yielded reliability coefficient of 0.78 .

\section{Scoring of SPST}

5 marks for each sub-question in question 1; 7 marks for (a) 9 marks for (b); 2 marks for eachf sub quesions; 2 marks for each sub question.

\section{Validation of SAT}

For SAT, reliability coefficient was computed using Kuder-Richardson formula - 20, since all the test items were not of equal difficulty level. The KR-20 value obtained was 0.89 , average item difficulty index, obtained was 0.46 and the discriminating index was 0.82 .

\subsection{Scoring of SAT}

SAT was scored by giving each to every correct response.

\subsection{Validation of S MAT}

Test was administered twice with a time lag of 2 weeks. The test-re-test reliability coefficient was then computed and found to be 0.79 using Pearson's Products Moment Correlation formula.

\subsection{Scoring of SMAT}

SMAT was scored by awarding 1 mark to each correct and zero for wrong ones. Pupils were awarded marks based on their scores in the test. A total score was obtained for each pupil. The pupils were then grouped into three academic abilities viz: High, Medium and low based on their total scores.

\subsection{Procedure for Data Collection}

The questionnaires were administered to both the teachers and SS II students by the researchers and some research assistants and they were retrieved immediately. Mathematical Ability Test (MAT) and SMAT were first administered on the same day while SPST was done on another chosen day. SAT was administered last.

\subsection{Method of Data Analysis}

Multiple Regression Analysis was used to analyse the data collected from both the students and teachers. Answers were provided through this medium to the research questions raised in the study.

\section{Results and Discussion}

\subsection{Results}

Results obtained are presented as follows:

Table 1. Summary of regression analysis on the school factors and achievement

\begin{tabular}{|c|c|c|c|}
\hline $\mathbf{R}$ & $\begin{array}{c}\text { R Square } \\
\text { (R2) }\end{array}$ & $\begin{array}{c}\text { Adjusted R } \\
\text { square }\end{array}$ & $\begin{array}{c}\text { Standard Error } \\
\text { of the Estimate }\end{array}$ \\
\hline 0.608 & 0.369 & 0.366 & 1.5347 \\
\hline
\end{tabular}

From Table 1, there is a positive multiple correlations among the four school factors viz: school location, school type, laboratory adequacy and frequency of practical classes and student's achievement in Chemistry $(\mathrm{R}=.608)$. This shows that the four school factors listed are important factors when the prediction of students' achievement in Chemistry is in focus. The table also shows an adjusted $\mathrm{R}^{2}$ value of .366 which implies that $36.6 \%$ of the total variance in student achievement in Chemistry is due to the four school factors. The remaining $63.4 \%$ is ascribed to other factors not investigated in the study and errors. In order to test the significance of the adjusted $\mathrm{R}^{2}$ value.

Table 2. Analysis of variance of regression on school factors and achievement

\begin{tabular}{|l|c|c|c|c|c|}
\hline \multicolumn{1}{|c|}{ Source of variance } & Sum of squares & Df & Mean square & F & Sig. \\
\hline Regression & 1132.930 & 4 & 283.232 & 120.254 & $.00 *$ \\
Residual & 1933.686 & 821 & 2.55 & & \\
Total & 3066.616 & 825 & & & \\
\hline
\end{tabular}

* Significant at $\mathrm{p}<0.5$

Table 2 shows that the $\mathrm{R}-$ value of 0.61 is significant $(\mathrm{F}(4.821)=120.256 ; \mathrm{p}<05)$. Thus, the $\mathrm{R}$ value is not due to chance. With these results, there is significant composite effect of the school factors in students' achievement in Chemistry 
Table 3. Relative effect of school factors on achievement

\begin{tabular}{|l|c|c|c|c|c|l|}
\hline \multicolumn{1}{|c|}{ School Factor } & $\mathrm{B}$ & Std. Error & Beta & Ran & $\mathrm{t}$ & Sig. \\
\hline (constant) & 43.168 & 1.565 & & & 27.578 & .000 \\
School location & -5.509 & .320 & .669 & $1 \mathrm{st}$ & 17.237 & $.000^{*}$ \\
School type & .801 & .601 & .059 & 4 th & 1.33 & $.000^{*}$ \\
Laboratory Adequacy & -.690 & .062 & .515 & $2^{\text {nd }}$ & 11.182 & $.000^{*}$ \\
Frequency of practical classes & 1.552 & .142 & .358 & 3 rd & 10.926 & $.000^{*}$ \\
\hline
\end{tabular}

* Significant at $\mathrm{P}<.05$

From table, school location made the highest contributions to the achievement in Chemistry $(\beta=.669 ; p<.05)$. The second is the rank of relative contributions is by laboratory adequacy $(\beta=515$; $p$ $<.05)$ while frequency of practical classes made the third in the order of magnitude of contributions $(\beta=$ $.385 ; \mathrm{p}<.05)$. These three factors made contributions which were found to be significant. Also, the table shows that school type made the lowest contributions to achievement in Chemistry $(\beta=.059 ; \mathrm{p}<.05)$ and this is not significant.

The order of decreasing magnitude is presented as: School location > Laboratory adequacy > frequency of practical classes $>$ school type.

\subsection{Discussion}

The study found that the four school factors taken together correlate positively with achievement in chemistry $36.6 \%$ was the contribution modern achievement for achievement in chemistry, school location, laboratory adequacy and frequency of practical classes made significant contribution. These findings lend credence to the concerns raised in the senior secondary school chemistry curriculum that factors such as school location, laboratory adequacy (availability and adequacy of materials, equipment and apparatus) could be difficulties in the implementation of the chemistry curriculum. The findings, of this study is in agreement with Ogunleye and Odubunmi and Balogun that school location contributed significantly to the achievement of students in chemistry. However, study such as that of Daramola did not find such significant contribution.

Butin's emphasis on the educational trends in science facilities tending towards provision of adequate laboratory for all students provides support for findings of this study in terms of laboratory adequacy as having a direct effect on students' achievement in chemistry.

Tatli and Ayas and Trundade, Fiolhai and Almedia also affirmed that by maximizing interactivity, laboratory practical applications render students active thinkers instead of passive observers and thereby construct effective and meaningful learning process [60]. They emphasized that some experiment that can only be performed using a demonstration method, for reactions such as lack of laboratories, insufficient materials and crowded classroom. For these experiments, it is clear that virtual laboratory can provide a valuable alternative to traditional laboratory applications. This findings also corroborates those of Wisconsin et al, Bajah, Okegbile and Onwu [2], [49], [22].

The study also found that school type made no significant relative contributions to students' achievement in chemistry. This finding contradicts Olude and Demircioughi and Morman who found that there is significant relationship between school type and feelings related chemistry and chemistry achievement among school children [63].

\subsection{Summary}

This study sought to determine the extent to which school factors could predict students' achievement in chemistry. Three (3) research questions were raised and answers were provided to the questions based on the data collected through the research instruments designed and developed for the study.

Data were analyzed using Multiple Regression Analysis and the findings of the study are summarized in the list below:

- The school factors correlate positively with students' achievement in chemistry. They jointly contribute $36.6 \%$ to the variance in students' achievement in Chemistry.

- When school factors only were considered, only three out of the four factors made significant relative contributions to the variance in student achievement in Chemistry. These include laboratory adequacy and frequency of practical classes. School type made no significant relative contribution in this regard.

\subsection{Conclusion}

From the findings, it is concluded that three out of four independent variables could predict the dependent variable. For student's achievement, school location, laboratory adequacy and frequency of practical classes were predictors as they have significant effects on the academic achievement of chemistry students especially at secondary school 
level. School type was found to have significant effect on students' achievement in chemistry. These factors have indicated the area that need to be addressed in order to enhance the learning outcomes of students in chemistry. If the government and other stakeholders in education industry could improve on the school factors, it is very likely that students' achievement in chemistry will improve.

\subsection{Recommendations}

The following recommendations are hereby made based on the findings of the study.

- Government and school authorities should through the allocation of funds, materials and apparatus for sciences teaching make school laboratories more adequate for effective implementation for Chemistry curriculum so as to enhance the performance of students.

- A range of authentic assessment such as hands on performance tasks, constructed response investigations and open-ended questions are recommended.

- Students should be exposed to more laboratory applications and activities so that they can recognize laboratory materials and equipment.

- A compulsory practical examination at the JSCE is also suggested.

- It is the investigators' opinion that various schools should find a way of helping in generating funds for the laboratories.

- Chemistry teachers too should try to improvise materials for practical work where possible so as to lighten the financial burden of school administrators while the government should improve on the funding of schools to alleviate this problem.

- Practical activities should be taught by techniques that will generate interest in students. It therefore follows that the students who do not show significant interest in Chemistry are not likely to internalize concepts learnt in this subject and may consequently not able to apply them in life experience.

\section{References}

[1] A. Roychouldhury, and M.W. Roth, "Interactions in an Open Inquiry Physics Laboratory", International Journal of Science Education, 1996, pp. 423-445.

[2] A. Wisconsin, and A. Helming, Students/Teacher Achievement Ratio Tennessee's K-3 class study, State department of Education, Nashville Tennessee, 1991.

[3] A.A. Adeyegbe, "In search of indices for measuring the standard of education: A need for a shift in paradigm" $A$ paper presented at a special seminar for West African Examinations Council, Lagos, 2005.
[4] A.A. Nwosu, "Levels of acquisition of science process skills among year one senior secondary school students" Journal of science teachers' association of Nigeria 29 (18), Lagos, 1994, pp. 47 - 53.

[5] A.A. Nwosu, and E.A. Okeke, "The effect of teacher sensitization of students' acquisition of science process skills", Journal of the Science Teachers Association of Nigeria 30 (1\&2), Lagos, 1995, pp. $39-45$.

[6] A.B. Abbas, "Achieving National Economic Empowerment and Development Strategy through Chemistry", STAN Conference Proceedings, Lagos, 2007.

[7] A.M. Oginni, "Students attitude indices as predictors of learning outcomes in chemistry", British journal of art and social sciences, Vol 8 (11), London, 2012, pp. 174-182.

[8] A.M. Olagunju, F.A. Adesoji, T.O. Iroegbu, and T.A. Ige, "Innovations in science teaching for the new millennium. In Bamisaye, O.A; Nwazuoke, I.A. and A. Okediran (Eds) Education, 2003.

[9] A.O. Ogunleye, "A survey of students' performance in science Lagos State of Save Science Education Appeal fund", Journal of Teachers Association of Nigeria, Lagos, 1999 , pp. $15-20$.

[10] A.T. Jimoh, "Sustaining Technological Development in Africa: The position of analytical chemistry in Nigerian Secondary School", STAN: Science, Technology and Mathematics, Lagos, 2002.

[11] Ababio, O.Y., The New School Chemistry for Senior Secondary Schools, Africa Fast Publishers Ltd, Onitsha, 2005 .

[12] B. Kobune, "Mapping out schools delivering waterdown education", Work and learning: Business Day, Tuesday 4 March, 2008, pp. 31.

[13] B.C. Aguisiobo, Lboratory and resources utilization, funding and management by integrated science teachers. African journal of education, 1[1], 1998, pp. 29 - 36.

[14] C. Nwagbo, "Enriching science, technology and mathematics (STM) Education through teaching for inculcation of scientific literary", $41^{\text {st }}$ Annual Conference of STAN proceedings, Lagos, 2000, pp. 372-375.

[15] Capron, C. and M. Duyne, "Assessment of effects of socio-economic status in IQ in a full cross fostering study mature", Conference Proceedings 3(40), New York, 1992. Pp. $552-554$.

[16] F.A. Adesoji, "Knowledge of Integrated Science of Pre-requisite Capability for First Year Senior Secondary School Sciences and Implication for Teacher Education in Abimbade, A. (ed)", Teaching Preparation in the Twenty First Century. Development of Teacher Education, 1999, pp. $77-81$.

[17] F.I. Onwuakpa, "Communicating Science, technology and Mathematics and Implications for the Teacher", Journal of Science Teachers' Association of Nigeria, 39th Annual Conference Proceedings, 1998, pp. 96-100. 
[18] Federal Ministry of Education, National Policy on Education (Revised). NERC Press, Lagos, 1995.

[19] Federal Ministry of Education, Policy on Education (Revised), NERC Press, Lagos, 1998.

[20] Federal Republic of Nigeria (2004). National Policy on Education. NERDC Press, Lagos, 2004.

[21] G.A. Ajewole, "Science and technology in secondary schools: Need for manpower development", Journal of Science Teachers Association of Nigeria 40 (1\&2), Lagos, 2005, pp. $63-67$.

[22] G.O. Onwu, "Learning difficulties in Chemistry: Capacity Limitation or strategy deficit", African Journal of Educational Research 4[1\&2], 1981, pp. 125.

[23] H. Frazer, P. Okebukola, and O. Jegede, “Assessment of the learning Environment of Nigerian Science laboratory classes", Journal of the Science Teachers' Association of Nigeria 27(2), NERC Press, Lagos, 1992, pp. 1-17.

[24] I.E. Umoinyang, "Reducing noise factor on verbal and non-verbal communication of science and mathematics", Journal of Science Teacher's Association of Nigeria $9^{\text {th }}$ Annual Conference Proceedings, Lagos, 1998, pp. 46 - 47.

[25] J. Durant, "Science Education and public understanding of science". British Council Newsletter (123), 1995.

[26] J. French, Accomplishing scientific instruction, in $R$. Miller(ed). Doing Science: Images of science in science Education. Falmer, London, 1989, pp. 10-37.

[27] J. Shinho, "Establishing the field of science education policy" In analysis of mathematics and science initiatives in the U.S. Science Education International, 2004, pp. 45361

[28] J.F. Donnelly, "The place of laboratory in secondary science teaching", International Journal of Science Education 20[5], University Press, Lagos, 1998, pp. 585596.

[29] J.J. Gallagher, A summary of Research in Science Education. Macmillian, London, 1987, pp. 71, 277-284.

[30] J.R. Okpara, "Refocusing in Science, Technology and mathematics Education in Nigeria: Issues, Challenges and he way forward", $45^{\text {th }}$ Annual Conference Proceedings of STAN, Lagos, 2004, pp. 43-49.

[31] K. O. Aluko, "Strategies for promoting women participation in Science, Technology and Mathematics STM" STAN Annual 42' Conference Proceeding 184-189. O.O. Busari (Ed). Heinemann Educational Books, Ibadan, 2001.

[32] Kneeves, J.P. Learning science in the changing world: Gross-National Studies of Science Achievement, IEA Headquarters, Australia, 1992.

[33] Lee, K.L., Goh, N. Chia L \& Chin C (1996). Cognitive Variables in problem solving in chemistry. A revisited study, Science Education 80(6), 691-170.

Copyright () 2013, Infonomics Society
[34] M.A. Maduabum, "Accountability in senior secondary school science achievement in Nigeria: A joint responsibility", Lagos Journal of Science education, Lagos, 1992, pp. 50-58

[35] M.U. Adelabu, "Schools and water management in social studies. Obodi et al (Eds)", Book of Readings on Education, Environment and Sustainable Development, Cardinal Crest Ltd, Ibadan, 1998.

[36] Mordi, C.O. Socio-cultural factors and achievement in the second science study. An unpublished Ph.D Thesis University of Ibadan, Ibadan, 1983.

[37] N. Effiong-Edem, "Optimization of common laboratory equipment in the teaching of integrated science" $41^{\text {st }}$ STAN proceedings, Lagos, 2001, pp. $204-208$.

[38] Ndukwu, P.N., School and teacher factors material resources utilization in pre-primary schools in Lagos State. Unpublished Ph.D Thesis. University of Ibadan, Ibadan, 2002.

[39] Odinko, M.N., Home and School Factor as determinants of Literacy Skill Development among Nigeria Preprimary School Children, Unpublished Ph.D. Thesis. University of Ibadan, Ibadan, 2002.

[40] Ogunleye, B.O., Evaluating the environmental aspect of the senior secondary school chemistry curriculum in Ibadan. Unpublished Ph.D Thesis, University of Ibadan, Ibadan, 2002.

[41] Olarewaju, A.O., New Approaches to the Teaching of Integrated Science, Alafes Nigerian Company, Ibadan, 1994.

[42] Orji, U.E., Secondary School Students Learning Problems, Attitude and Performance in Igbo as a second Nigerian Language in Oyo State.Unpublished Ph.D.Thesis.University of Ibadan, Ibadan, 1998.

[43] P. Garner, (1994): Metacognition and Executive Control.In R.E. Rudell, and H. Singer(eds). Theoretical model and processes of reading (4th Edition), New York, Mark D.E. International Reading Association.

[44] P.N. Okafor, "Laboratory Resources and Utilization as Correlates of Chemistry Student's learning Outcomes", 41st Annual Conference proceedings of the Science Teachers Association of Nigeria, 2001, pp. 169-173.

[45] R. A. Olatoye, and M.O. Afuwape, "Students integrated science achievement as a predictor of later achievement in Biology, Chemistry and Physics" Journal of the Science Teachers Association of Nigeria. 39 (1\& 2), 2004, pp. $11-16$.

[46] S.C. Okonkwo, "Relationship between some school and teacher variables and students' achievement in Mathematics", Journal of science Teachers Association of Nigeria 35 ( $1 \& 2$ ), 2002, pp. 43 - 49.

[47] S.C. Okonkwo, "Status of Students' readiness for Junior Secondary School Mathematics", Journal of Quality Education, 1997, pp. 154 - 166. 
[48] S.O. Adeyegbe, "The senior secondary school science curricula and candidates performance an appraisal of the first cycle of operation" Journal of science Teacher Association 28 (142), Lagos, 1993, pp. 3 - 12

[49] S.O. Okegbile, "Evaluation of practical Lessons in Science", A paper presented at the managerial Conference of school of science Education at the Federal College of Education, Osiele Abeokuta, 1996.

[50] Salt, D., Variety and Anti-variety Science Teacher Education, 1998.

[51] Solomon, J., "School Laboratory Life in practical Science in B.E. Woolnough (ed)", the role and reality of practical work in school science, Open University press, Million Keynes, 1991, pp. 101-111.

[52] T. Solarin, "Private schools and Equal Education Opportunities in Nigeria Education and Development", Journal of Nigeria Educational Research Council (2), 1977, pp. 161-168.

[53] T.O. Ogunmade, "An essay on Piagetian Formal Operation State to Chemistry Teaching and Learning in Secondary Schools", Lagos Journal of Science Education 2(2), Lagos, 1994, pp. 44-48.

[54] T.T. Lasisi, "Improving communication skills of sciences students in tertiary institutions: the use of writing consultants approach", Journal of science teachers association of Nigeria $39^{\text {th }}$ Annual Conference Proceedings, Lagos, 1998, pp. 369-371.

[55] Thide and Treagust, "Using analysis to an understanding a secondary chemistry education", A paper presented at the Royal Australian Chemical Institute Conference in Chemical Education, 1994.

[56] Banya, S.K., Study of factors affecting attitude of young female students towards chemistry at the high school level. Ph.D dissersation at the College of Science and Technology, University of Southern Mississippi, 2005.

[57] Wong, A.F.L. and Fraser, B., Environment attitude association in the chemistry laboratory classrooms. Research in science and technology education, 1996, 14(1), $91-102$.

[58] R. Tai, P.M. Sadler and J.F. Loehr. "Factors influencing success in introductory college chemistry". Journal of research in science teaching, 2005, 42(9), pp. $987-1012$.

[59] Ogunmade, T.O., The status of quality teaching and learning of science in Lagos State secondary schools. Unpublished Ph.D Thesis, Edith Cowan University, Perth, Western Australia, 2006.

[60] Tatli, Z. and Ayas, A. Effects of a virtual chemistry laboratory on students' achievement. A Journal of Educational Technology and Society, 2011, 16(1), 159 170.

[61] J. Trindade, C. Fiolhais and L. Almedia "Science learning in virtual environment: A descriptive study".
British Journal of Educational Technology, 2002, 33(4), $471-488$

[62] N. Ozdener, "Using simulation for experimental teaching methods". Turkish Online Journal of Educational Technology, 2005, 4(4), 93 - 98.

[63] Olude, A.S. Effects of school type on students' achievement in chemistry. Unpublished B.Sc. Ed Project Lagos State University, Lagos, 2005.

[64] Demircioglu, H. \& Norman, N. Effects of some variables on chemisrtry achievement and chemistry-related altitudes of high school students. Hacettepe University, Egitim, 1999, 16 - 17; 40 - 44. 